\title{
Intractable convulsion in critically ill children
}

\section{Corresponding author:}

Nagwan Yossery Saleh

Pediatrics, Faculty of Medicine,

Menoufia University Hospital, Egypt

e-mail: drnagwan80@gmail.com
Medical Research Journal 2020;

Volume 5, Number 2, 61-67 10.5603/MRJ.a2020.0013

Copyright (C) 2020 Via Medica ISSN 2451-2591

\begin{abstract}
Introduction: To determine the etiology of intractable convulsion, the outcome of intractable convulsions in pediatric patients and risk factors related to poor outcome.

Material and methods: This case-control study conducted on 100 children where 50 patients who fulfilled the criteria for intractability admitted into pediatric intensive care unit (PICU) and 50 epileptic children on appropriately chosen antiepileptic drug (AED) with no seizures for more than 1 year who attending to the pediatric neurology clinic for follow up. Full history taking, examination, investigations performed for patients groups on admission and then followed up to six months for an outcome.

Results: This study showed no significant difference between studied groups as regard age, sex, consanguinity and positive family history but noticed a highly statistically significant increase in prenatal problems ( $\mathrm{n} ; 20$ patients), neonatal seizure ( $\mathrm{n} ; 15$ patients), and postnatal problem ( $\mathrm{n} ; 10$ patients) in intractable groups compared to controlled groups ( $p$ value 0.001). Delayed developmental history ( $n$; 40 patients) was significantly higher among intractable groups compared to controlled groups ( $p$ value 0.001). Intractable groups had significantly increased in abnormal neurological examination than controlled groups ( $p$ value 0.001). History of prenatal problems, neonatal seizures, delayed developmental milestones, presence of underlying etiology of seizures, and abnormality findings in EEG and neuroimaging are risk factors for the intractability of convulsion. There was a significant relation between poor outcome and other studied variables including being female, presence of consanguinity, delayed developmental milestones, disturbed level of consciousness and secondary etiology of seizures ( $p$ value; 0.04, 0.003, 0.001, 0.0010 .001 respectively). Conclusion: The most common etiology of intractability in epileptic children is a secondary etiology of seizures. Early detection of risk factors for intractable epilepsy is important to decrease intractability complications. Proper perinatal care is important for decreasing prevalence of intractable epilepsy.

Key words: convulsion; epilepsy; intractable convulsion; outcome
\end{abstract}

Med Res J 2020; 5 (2): 61-67

\section{Introduction}

Convulsion is the most common neurological diseases in pediatric patients and account one time in $4-10 \%$ of children in the first 16 years of life [1]. Convulsion defined as a paroxysmal and transient occurrence of signs or symptoms resulting from abnormal neuronal activity originated in the brain [2].

Epilepsy is chronic brain diseases diagnosed by recurrent spontaneous convulsions, which start in the childhood period. Refractory and repeated convulsions can cause long-term cognitive impairment, lower of social participation and decreased quality of life. About $30 \%$ of patients with epilepsy; the convulsions are intractable, $70 \%$ of these patients become controlled with antiepileptic drugs [3].
Intractable convulsion is a life-threatening medical emergency that needs urgent recognition and emergency treatment to decrease morbidity and mortality. The predictors of the intractability of convulsions are the presence of a structural lesion, abnormal neurological state and early onset of convulsion [4].

The intractable convulsion diagnosed as a failure of adequate two or more tolerated, suitable chosen anticonvulsant drug schedules whether as monotherapies or in combination to achieve optimum freedom from convulsion [5].

The patients considered as intractable when they developed at least one convulsion or more per month in a 6-month period although being treated with at least 2 appropriately chosen antiepileptic drugs [6]. 
The aim of this study was to detect the etiology, risk factors related to intractability and poor outcome of convulsion in children.

\section{Material and methods}

The study was performed from September 2016 to July 2018 and was approved by the local Ethical Committee. A written informed consent for each child was obtained from their parents prior to inclusion. In this case-control study, 100 children enrolled in the study aged 12 months to 12 years old, where epileptic children were selected from PICU and outpatient clinic from the Pediatric Neurology Unit, Pediatric Department, Menoufia University Hospitals. These children were divided into two main groups, which included: Group I included 50 epileptic children who fulfilling the criteria for intractability, they were 18 males (36\%) and 32 females (64\%). Group II included 50 epileptic children on AEDs with no seizures for more than 1 year, they were 22 males (44\%) and 28 females (56\%). They underwent full history taking, clinical examinations and investigation.

Inclusion criteria in the study if patient involves any of the following; 1) Epileptic children with intractability (failure of 2 or more first-line antiepileptic drugs to control seizures in children who had 1 or more seizures per month for 2 years). 2) Age from 2 to below 18 years.

Exclusion criteria including one of these; Patients with single unprovoked seizures, Patients with provoked seizures, Patients with poor compliance regarding regular drug intake or appearance of drug side effects, Patients with unsuitable drug choice, and Patients with an inborn error of metabolism.

All patients subjected to full history taking including; age, sex, residence, consanguinity, family history of epilepsy, prenatal insult, neonatal seizure and developmental history. Clinical examination including; general examination (HR, RR, Temp, and B.P), anthropometric measurements in form of Wt. in $\mathrm{kg}$, $\mathrm{Ht}$. in $\mathrm{cm}$, head circumference in $\mathrm{cm}$, and body mass index and assessment of developmental milestones and examine neurological reflexes.

For all patients; laboratory investigations withdrawn including complete blood count (CBC), serum electrolytes ( $\mathrm{Na}, \mathrm{K}$, and $\mathrm{Ca}$ ), Neuroimaging study including $\mathrm{CT}$, $\mathrm{MRI}$ and EEG .Eventually, All patients were followed up for 6 months after discharge from the Pediatric Intensive Care Unit(PICU) .

\section{Assessment of developmental milestones}

Developmental milestones assessed according to the age of achievement of these milestones. To assess the onset of key developmental milestones without having to complete an entire standardized assessment, urgent milestones from motor and language domains chosen. All questions took the format: 'At what age did he/she first...' and in this study, we use data from one 'early' and one 'late' milestone, e.g., 'Sit without support' and 'Walk independently' (gross motor), 'Pick up a small object with a pincer grip, i.e., with thumb and forefinger' and 'Stack at least three small blocks or other small objects; stack must not fall'(fine motor), 'Say their first word' and 'Put two or more words together' (language) [7].

Delayed milestone, also called developmental delays, considered when a child does not reach one of these stages at the expected age. But, in most cases, a wide variety of ages can be considered normal, and not a cause for medical concern. Milestones are often measured using percentiles, and for many milestones, a value between the 5th and 95th percentile does not require intervention, though values towards the edges of that range can be associated with other medical conditions. It is not possible to treat. The measurement of posture sway may be an early indicator [8].

\section{Statistical analysis}

Data were collected, tabulated, statistically analyzed using a personal computer with Statistical Package of Social Science (SPSS) (version 20; Inc., Chicago .IL) where the following statistics were applied. Two types of statistics were done: Descriptive statistics e.g. Number (No), percentage (\%), mean $(X)$ and standard deviation (SD). The second was Analytic statistics: Chi-squared test $(\chi 2)$, student $t$-test $(\mathrm{t})$, Kruskal Waills test $(\mathrm{K})$, one-way Anova test $(F)$, Mann-Whiteny test $(U), P$-value $\leq 0.05$ to be statistically significant, $\mathrm{P}$-value $\leq 0.001$ to be highly statistically significant. Values were expressed as means and standard deviations or counts and percentages as appropriate.

\section{Results}

The socio-demographic data of studied groups showed no statistically significant difference between studied groups as regard age, sex, consanguinity and positive family history but showed a highly statistically significant increase in prenatal insult and postnatal problem in intractable groups compared to controlled groups $(p=0.001)$. Delayed developmental history was significantly higher among intractable groups compared to controlled groups $(p=0.001)$. Neonatal seizure in the form of partial seizures, myoclonic seizures and infantile spasms were more frequent in children with intractable convulsion (Tab. 1).

Neurological examination of studied groups showed a highly significant increase in neurological abnormality 
Table 1. Socio-demographic data of all studied patients

\begin{tabular}{|c|c|c|c|c|c|c|}
\hline Demographic data & \multicolumn{2}{|c|}{ Group I } & \multicolumn{2}{|c|}{ Group II } & $x^{2}$ & $p$ value \\
\hline $\begin{array}{l}\text { Age in years } \\
\text { Range } \\
\text { Mean } \pm S D\end{array}$ & \multicolumn{2}{|c|}{$\begin{array}{c}1-12 \\
4.1 \pm 4.2\end{array}$} & \multicolumn{2}{|c|}{$\begin{array}{c}3-12 \\
4.5 \pm 3.8\end{array}$} & 0.74 & 0.45 \\
\hline Sex & No & $\%$ & No & $\%$ & & \\
\hline $\begin{array}{l}\text { Male } \\
\text { Female }\end{array}$ & $\begin{array}{l}18 \\
32\end{array}$ & $\begin{array}{l}36 \\
64\end{array}$ & $\begin{array}{l}22 \\
28\end{array}$ & $\begin{array}{l}44 \\
56\end{array}$ & 2.3 & 0.59 \\
\hline Consanguinity & No & $\%$ & No & $\%$ & & \\
\hline $\begin{array}{l}\text { Positive } \\
\text { Negative }\end{array}$ & $\begin{array}{l}21 \\
29\end{array}$ & $\begin{array}{l}42 \\
58\end{array}$ & $\begin{array}{l}15 \\
35\end{array}$ & $\begin{array}{l}30 \\
70\end{array}$ & 2.4 & 0.48 \\
\hline Family history of epilepsy & No & $\%$ & No & $\%$ & & \\
\hline $\begin{array}{l}\text { Positive } \\
\text { Negative }\end{array}$ & $\begin{array}{l}26 \\
24\end{array}$ & $\begin{array}{l}52 \\
48\end{array}$ & $\begin{array}{l}20 \\
30\end{array}$ & $\begin{array}{l}40 \\
60\end{array}$ & 6.9 & 0.067 \\
\hline Prenatal problems & No & $\%$ & No & $\%$ & 36.1 & \\
\hline $\begin{array}{l}\text { NO insult } \\
\text { Kernicterus } \\
\text { Cyanosis } \\
\text { Obstructed labor with HIE }\end{array}$ & $\begin{array}{c}30 \\
5 \\
5 \\
10\end{array}$ & $\begin{array}{l}60 \\
10 \\
10 \\
20\end{array}$ & $\begin{array}{l}37 \\
3 \\
5 \\
5\end{array}$ & $\begin{array}{c}74 \\
6 \\
10 \\
10\end{array}$ & & $0.001^{*}$ \\
\hline Neonatal seizure & No & $\%$ & No & $\%$ & & $0.001 *$ \\
\hline $\begin{array}{l}\text { Positive } \\
\text { Negative }\end{array}$ & $\begin{array}{l}15 \\
35\end{array}$ & $\begin{array}{l}30 \\
70\end{array}$ & $\begin{array}{c}9 \\
41\end{array}$ & $\begin{array}{l}18 \\
82\end{array}$ & 28.7 & \\
\hline Postnatal problem & No & $\%$ & No & $\%$ & 28.8 & \\
\hline $\begin{array}{l}\text { Positive } \\
\text { Negative }\end{array}$ & $\begin{array}{l}10 \\
40\end{array}$ & $\begin{array}{l}20 \\
80\end{array}$ & $\begin{array}{c}8 \\
42\end{array}$ & $\begin{array}{l}16 \\
84\end{array}$ & & $0.001^{*}$ \\
\hline Developmental history & No & $\%$ & No & $\%$ & 74.2 & \\
\hline $\begin{array}{l}\text { Normal } \\
\text { Delayed } \\
\text { Lost after being acquired }\end{array}$ & $\begin{array}{l}10 \\
30 \\
10\end{array}$ & $\begin{array}{l}20 \\
60 \\
20\end{array}$ & $\begin{array}{c}25 \\
25 \\
0\end{array}$ & $\begin{array}{c}50 \\
50 \\
0\end{array}$ & & $0.001^{*}$ \\
\hline
\end{tabular}

$\mathrm{X}^{2}$ - Chi square test; *statistically significant $\mathrm{p} \leq 0.05$; HIE — Hypoxic Ischemic Encephalopathy; Group I — intractable epileptic patients; Group II - controlled epileptic patients

in intractable groups than controlled groups regarding mentality, speech, cranial nerve and motor system assessment ( $p=0.001)$ (Tab. 2).

Also, this study noticed a highly significant difference between the two studied groups; intractable epileptic group and controlled epileptic group, regarding the number of antiepileptic drugs taken to control convulsions $(p=0.001)$ (Tab. 3$)$.

History of prenatal problems, neonatal seizures, delayed developmental milestones, presence of underlying etiology of seizures, abnormality in Electro Encephalograms (EEG) and Neuroimaging studies are risk factors for the intractability of convulsion $(p=0.001)$ (Tab. 4).

As regarding the etiology of seizures, there was a significant increase in secondary causes in intractable groups than controlled groups $(p=0.001)$ (Tab. 5).

There was a significant relation between poor outcome and other studied variables including being female, presence of consanguinity, delayed developmental milestones and disturbed level of consciousness and secondary etiology of seizures (Tab. 6).

\section{Discussion}

Intractable convulsions in children are a life-threatening disease with serious risk of neurological insults which considered a medical emergency [9]. Epilepsy accounts for more than $50 \%$ of children, and refractory epilepsy is a big problem in this age group [10].

Only $3 \%$ of children fail to respond to the first two anticonvulsants drugs become seizure-free by using a third anticonvulsant drug, while the convulsions become intractable in about one-third of these children [11].

In our study, there was highly statistically significant difference between the two groups as regarding 
Table 2. Neurological examination of studied patients

\begin{tabular}{|c|c|c|c|c|c|c|}
\hline Neurological examination & & & & & $\mathbf{X} 2$ & $p$ value \\
\hline Mentality & $\mathrm{N}$ & $\%$ & $\mathrm{~N}$ & $\%$ & & \\
\hline $\begin{array}{l}\text { - Normal } \\
\text { - Low }\end{array}$ & $\begin{array}{l}18 \\
32\end{array}$ & $\begin{array}{l}36 \\
64\end{array}$ & $\begin{array}{l}35 \\
15\end{array}$ & $\begin{array}{l}70 \\
30\end{array}$ & 38.2 & $0.001^{*}$ \\
\hline Speech & $\mathrm{N}$ & $\%$ & $\mathrm{~N}$ & $\%$ & 36.2 & $0.001^{*}$ \\
\hline $\begin{array}{ll}\text { - } & \text { Normal } \\
\text { - Delayed } \\
\text { - }\end{array}$ & $\begin{array}{c}15 \\
33 \\
2\end{array}$ & $\begin{array}{c}30 \\
66 \\
4\end{array}$ & $\begin{array}{c}35 \\
15 \\
0\end{array}$ & $\begin{array}{c}70 \\
30 \\
0\end{array}$ & & \\
\hline $\begin{array}{l}\text { Cranial nerve } \\
\text { - } \quad \text { Normal } \\
\text { - } \quad \text { Affected }\end{array}$ & $\begin{array}{l}N \\
33 \\
17\end{array}$ & $\begin{array}{l}\% \\
66 \\
34\end{array}$ & $\begin{array}{l}N \\
40 \\
10\end{array}$ & $\begin{array}{l}\% \\
80 \\
20\end{array}$ & 40.7 & $0.001^{*}$ \\
\hline Motor system & $\mathrm{N}$ & $\%$ & $\mathrm{~N}$ & $\%$ & & \\
\hline $\begin{array}{l}\text { A. Power } \\
\text { - Normal } \\
\text { - Weakness }\end{array}$ & $\begin{array}{l}25 \\
25\end{array}$ & $\begin{array}{l}50 \\
50\end{array}$ & $\begin{array}{l}25 \\
25\end{array}$ & $\begin{array}{l}50 \\
50\end{array}$ & 84.0 & $0.001^{*}$ \\
\hline $\begin{array}{l}\text { B. Tone } \\
\text { - Normal tone } \\
\text { - Hypotonia } \\
\text { - Hypertonia }\end{array}$ & $\begin{array}{l}25 \\
13 \\
12\end{array}$ & $\begin{array}{l}50 \\
26 \\
24\end{array}$ & $\begin{array}{c}38 \\
5 \\
7\end{array}$ & $\begin{array}{l}76 \\
10 \\
14\end{array}$ & 34.0 & $0.001^{*}$ \\
\hline
\end{tabular}

$\mathrm{X}^{2}-$ Chi square test; *Statistically significant $\mathrm{p} \leq 0.05$

Table 3. Response of studied groups to anti-epileptic drugs

\begin{tabular}{|c|c|c|c|c|c|c|}
\hline \multirow[t]{2}{*}{ Drug therapy } & \multicolumn{2}{|c|}{ Group I } & \multicolumn{2}{|c|}{ Group II } & \multirow[t]{2}{*}{ Test } & \multirow[t]{2}{*}{$p$ value } \\
\hline & $\mathrm{N}$ & $\%$ & $\mathrm{~N}$ & $\%$ & & \\
\hline Monotherapy control & 0 & 0 & 30 & 60 & 86.2 & $0.001^{*}$ \\
\hline Ditherapy control & 0 & 0 & 20 & 40 & 66.8 & $0.005^{\star}$ \\
\hline Polytherapy control & 43 & 86 & 0 & 0 & 74.9 & $0.002^{*}$ \\
\hline Uncontrolled drug therapy & 7 & 14 & 0 & 0 & 89.4 & $0.001^{*}$ \\
\hline
\end{tabular}

$\mathrm{X}^{2}-$ Chi-square test; * Statistically significant $\mathrm{p} \leq 0.05$

mentality, speech and motor system affection and also; Tripathi et al. [12] and Saygiet al. [13] found that there was an underlying etiology that affects the brain and motor system.

Our results revealed that there was a significant statistical difference between studied groups regarding response to drugs (monotherapy, polytherapy), where all patients with intractable convulsions needed polytherapy. This agreed with Smith et al. [14] as the definition of intractability depend on failure of treatment with two (or more) tolerated, appropriately chosen and used antiepileptic drug schedules (whether as one drug therapy or in combination) to achieve sustained seizure free [5]. Presence of underlying neurologic deficit points to either the intrinsic severity of epilepsy or to the severity of underlying etiology. These two factors may account for pharmacy resistance noticed by Patil et al. [15].
We found that there was a significant difference between studied groups regarding etiology where the secondary type of epilepsy (66\%) was more with intractable epileptic patients due to cerebral palsy (45.5\%) and post-traumatic intracranial hemorrhage (18.2\%). Kwan, et al. [16], Berg et al. [17] and Ohtsuka et al. [18] found that symptomatic epilepsy associated with intractability. In the study of Manoj et al. [19]; $71 \%$ of intractable epileptic children had remote symptomatic etiology, perinatal asphyxia constituted almost $50 \%$ children of intractable seizures and was an important predictor for intractability. In the study of Moinuddin et al. [20]; hypoxic-ischemic damage of the brain due to perinatal asphyxia and cerebral palsy were the main causes of symptomatic epilepsy.

We found that the presence of the history of prenatal problem, delayed developmental milestones, the secondary type of epilepsy, and neuroimaging studies abnormalities were risk factors for epilepsy intractability. 
Table 4. Risk factors of intractable convulsion in all studied groups

\begin{tabular}{|c|c|c|c|c|c|c|}
\hline \multirow{2}{*}{$\begin{array}{l}\text { Risk factors } \\
\text { Sex }\end{array}$} & \multicolumn{2}{|c|}{$\begin{array}{c}\text { Group I } \\
N=50\end{array}$} & \multicolumn{2}{|c|}{$\begin{array}{c}\text { Group II } \\
N=50\end{array}$} & \multirow{2}{*}{$\begin{array}{r}\mathbf{X} 2 \\
0.66\end{array}$} & \multirow{2}{*}{$\begin{array}{r}\text { p value } \\
0.041\end{array}$} \\
\hline & $\mathrm{N}$ & $\%$ & $\mathrm{~N}$ & $\%$ & & \\
\hline Male & 18 & 36 & 22 & 44 & & \\
\hline Female & 32 & 64 & 28 & 56 & & \\
\hline \multirow[t]{2}{*}{ History of prenatal problems } & $\mathrm{N}$ & $\%$ & $\mathrm{~N}$ & $\%$ & 0.8 & $0.001^{*}$ \\
\hline & 20 & 40 & 13 & 26 & & \\
\hline Presence of consanguinity & 21 & 42 & 15 & 30 & 1.5 & 0.21 \\
\hline Family history of convulsion or neurological disorder & 26 & 52 & 20 & 40 & 1.2 & $0.02^{\star}$ \\
\hline Abnormal developmental milestones & 40 & 80 & 25 & 50 & 9.8 & $0.001^{*}$ \\
\hline History of neonatal seizures & 15 & 30 & 9 & 18 & 9.1 & $0.002^{*}$ \\
\hline Presence of postnatal problem & 10 & 20 & 8 & 16 & 0.27 & 0.60 \\
\hline Partial type of seizure or partial with secondary generalization & 13 & 26 & 4 & 8 & 5.7 & $0.01^{*}$ \\
\hline Underlying etiology of seizures & 33 & 66 & 25 & 50 & 2.6 & $0.001^{*}$ \\
\hline Abnormal EEG finding & 39 & $78 \%$ & 29 & $58 \%$ & 4.5 & $0.03^{*}$ \\
\hline Abnormal neuroimaging studies & 22 & $44 \%$ & 10 & $20 \%$ & 6.9 & $0.001^{*}$ \\
\hline
\end{tabular}

*Statistically significant $p \leq 0.05$

Table 5. The most probable etiology of seizures among all studied patients

\begin{tabular}{|c|c|c|c|c|c|c|}
\hline \multirow[t]{2}{*}{ Etiology of epilepsy } & \multicolumn{2}{|c|}{ Group I } & \multicolumn{2}{|c|}{ Group II } & \multirow[t]{2}{*}{$\mathrm{X} 2$} & \multirow[t]{2}{*}{$p$ value } \\
\hline & $\mathrm{N}$ & $\%$ & $\mathrm{~N}$ & $\%$ & & \\
\hline Idiopathic & 17 & 34 & 25 & 50 & 66.1 & $0.001^{*}$ \\
\hline Secondary & 33 & 66 & 25 & 50 & 66.1 & $0.001^{*}$ \\
\hline Cerebral palsy & 15 & 45.5 & 20 & 80 & 12.56 & $0.002^{*}$ \\
\hline Neurodegenerative & 4 & 12.1 & 0 & 0 & & - \\
\hline Congenital Malformation & 5 & 15.1 & 0 & 0 & 3.184 & $\mathrm{FEp}=0.235$ \\
\hline *Post neuro-infection sequalae & 2 & 6.1 & 3 & 12 & 0.85 & 0.12 \\
\hline Post traumatic intracranial hemorrhage & 6 & 18.2 & 2 & 8 & 0.64 & $0.012^{*}$ \\
\hline Abscess & 1 & 3 & 0 & 0 & - & - \\
\hline
\end{tabular}

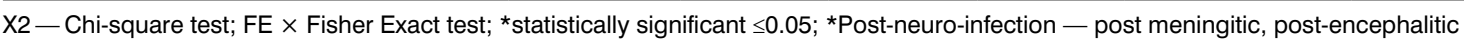

History of neonatal seizures associated with intractability risk caused by neuronal damage; during this period rapid brain development occur; so, most of these children demonstrate a history of prenatal asphyxia, congenital malformations and other factors that play an important role in the development of intractable epilepsy .accordingly type of neonatal seizures; partial seizures, myoclonic seizures and infantile spasms were more frequent in children with intractable convulsion and this agrees with the result of Joseph et al. [21]. Eriksson and Koivikko [22] stated that the presence of mixed seizure types, myoclonic seizures and infantile spasms may cause poor seizure control15. In the study of Chawla et al. [23], there was an association between myoclonic seizures and intractability.
There were significant relations between delayed developmental milestones, decreased conscious level, and etiology of convulsions, electrolyte disturbance and poor outcome of patients. Camfield et al. [24] and Berg et al. [25] found that the underlying diagnosis was the major predictor of mortality and outcome. And also Shinnar [26] found that an underlying congenital cause or early childhood brain damage causing neurodeficits is a strong predictor for a poor long-term seizure outcome.

\section{Conclusions}

Intractable Convulsion results from primary central nervous system insult or systemic disease with sec- 
Table 6. Relation between outcome with Socio-demographic data, clinical and etiology of intractable epileptic group

\begin{tabular}{|c|c|c|c|c|c|c|}
\hline \multirow[t]{2}{*}{ Socio-demographic data } & \multicolumn{4}{|c|}{$\begin{array}{c}\text { Outcome for patient } \\
\text { with intractable convulsion }\end{array}$} & \multirow[t]{3}{*}{$\mathrm{X} 2$} & \multirow[t]{3}{*}{$p$ value } \\
\hline & \multicolumn{2}{|c|}{ Poor } & \multicolumn{2}{|c|}{ Good } & & \\
\hline Sex & No & $\%$ & $\mathrm{~N}$ & $\%$ & & \\
\hline Male $\mathrm{N}=18$ & 8 & 16 & 10 & 20 & 3.6 & 0.04 \\
\hline Female $\mathrm{N}=32$ & 23 & 46 & 9 & 18 & & \\
\hline History of prenatal problems $\mathrm{N}=13$ & 9 & 18 & 4 & 8 & 0.3 & 0.8 \\
\hline Presence of consanguinity $\mathrm{N}=21$ & 8 & 16 & 13 & 26 & 8.7 & $0.003^{*}$ \\
\hline Family history of convulsion or neurological disorder $\mathrm{N}=26$ & 17 & 34 & 9 & 18 & 0.2 & 0.6 \\
\hline Abnormal developmental milestones $\mathrm{N}=40$ & 31 & 62 & 8 & 16 & 19.3 & $0.001^{*}$ \\
\hline $\begin{array}{l}\text { Seizure type } \\
\text { - } \text { Generalized N = } 37 \\
\text { - } \text { Partial N = } 13\end{array}$ & $\begin{array}{l}21 \\
10\end{array}$ & $\begin{array}{l}42 \\
20\end{array}$ & $\begin{array}{c}16 \\
3\end{array}$ & $\begin{array}{c}32 \\
6\end{array}$ & 1.6 & 0.19 \\
\hline $\begin{array}{l}\text { Conscious level } \\
\text { - Conscious N = 24 } \\
\text { - } \text { Disturbed N = 26 }\end{array}$ & $\begin{array}{c}5 \\
26\end{array}$ & $\begin{array}{l}10 \\
52\end{array}$ & $\begin{array}{c}19 \\
-\end{array}$ & 38 & 29.3 & $0.001^{*}$ \\
\hline $\begin{array}{l}\text { Associated electrolyte disturbance } \\
\text { - } \mathrm{NaN}=12 \\
\text { - } \mathrm{KN}=12 \\
\text { - } \mathrm{CaN}=19\end{array}$ & $\begin{array}{c}2 \\
1 \\
12\end{array}$ & $\begin{array}{c}4 \\
2 \\
24\end{array}$ & $\begin{array}{c}10 \\
11 \\
7\end{array}$ & $\begin{array}{l}20 \\
22 \\
14\end{array}$ & 12.1 & $0.002^{*}$ \\
\hline $\begin{array}{l}\text { Etiology } \\
\text { Idiopathic } \mathrm{N}=17 \\
\text { Secondary } \mathrm{N}=33\end{array}$ & $\begin{array}{c}0 \\
31\end{array}$ & $\begin{array}{c}0 \\
62\end{array}$ & $\begin{array}{c}17 \\
2\end{array}$ & $\begin{array}{c}34 \\
4\end{array}$ & 28.0 & $0.001^{*}$ \\
\hline
\end{tabular}

$\mathrm{X} 2$ - Chi-square test; * Statistically significant $\mathrm{p} \leq 0.05$

ondary central effect. The poor outcome associated with females more than males, in patients with a positive family history of epilepsy, delayed developmental milestones, patients with a disturbed conscious level and patients with secondary epilepsy.

\section{Disclosure}

The authors declare no financial or other conflicts of interest related to this work.

\section{Ethical approval}

All procedures performed in the study were in accordance with the ethical standards of the institutional research committee.

\section{Author's contributions}

FM: participated in data acquisition, data interpretation and revision of the manuscript. NS: participated in study design, data analysis, data interpretation, drafting, revision of the manuscript and correspondence.

\section{References}

1. Kheradmand Z, Yarali B, Zare A, et al. Comparison ofserum zinc and copper levels in children with intractable and controlled epilepsy. Iran J Child Neurol. 2014; 8(3): 49-54.

2. Kliegman RM, Stanton BF, St. Geme JW. et al. Nelson Textbook of Pediatrics. Elsevier, Saunders 2016.

3. Liu H, Yang Yi, Wang Y, et al. Ketogenic diet for treatment of intractable epilepsy in adults: A meta-analysis of observational studies. Epilepsia Open. 2018; 3(1): 9-17, doi: 10.1002/epi4.12098, indexed in Pubmed: 29588983.

4. Vasquez A, Gaínza-Lein M, Sánchez Fernández I, et al. Pediatric Status Epilepticus Research Group (pSERG). Hospital Emergency Treatment of Convulsive Status Epilepticus: Comparison of Pathways From Ten Pediatric Research Centers. Pediatr Neurol. 2018; 86: 33-41, doi: 10.1016/j.pediatrneurol.2018.06.004, indexed in Pubmed: 30075875.

5. Kwan P, Arzimanoglou A, Berg AT, et al. Definition of drug resistant epilepsy: consensus proposal by the ad hoc Task Force of the ILAE Commission on Therapeutic Strategies. Epilepsia. 2010; 51(6): 1069-1077, doi: 10.1111/j.1528-1167.2009.02397.x, indexed in Pubmed: 19889013

6. Ashrafi MR, Shams S, Nouri M, et al. A probable causative factor for an old problem: selenium and glutathione peroxidase appear to play important roles in epilepsy pathogenesis. Epilepsia. 2007; 48(9): 1750-1755, doi: 10.1111/j.1528-1167.2007.01143.x, indexed in Pubmed: 17555528

7. Kliegman RM, Bonita MD, Feigelman S. Growth, development and behavior. In: Kliegman RM, Stanton BF, St. Geme JW. et al. ed. Nelson textbook of pediatrics. 20 ed. Elsevier, Saunders 2016: chapter (10-12) table (10-1, 11-1, 13-1)

8. Deffeyes JE, Harbourne RT, Kyvelidou A, et al. Nonlinear analysis of sitting postural sway indicates developmental delay in infants. Clin Biomech (Bristol, Avon). 2009; 24(7): 564-570, doi: 10.1016/i.clinbiomech.2009.05.004, indexed in Pubmed: 19493596.

9. Grioni D, Landi A, Fiori L, et al. Does emergent implantation of a vagal nerve stimulator stop refractory status epilepticus in children? Seizure. 2018; 61: 94-97, doi: 10.1016/j.seizure.2018.08.008. 
10. Mikati M, Kliegman RM, Stanton BF. et al. Seizures in childhood Nelson textbook of pediatrics. In: Nelson textbook of pediatrics. 19th ed. Elsevier 2011: 2013-2033.

11. Wojciak RW, Mojs E Stanislawska-Kubiak M, et al. The serum zinc, copper, iron, and chromium concentrations in epileptic children. Epilepsy Res. 2013; 104(1-2): 40-44, doi: 10.1016/j.eplepsyres.2012.09.009, indexed in Pubmed: 23103060.

12. Tripathi M, Padhy UP, Vibha D, et al. Predictors of refractory epilepsy in north India: a case-control study. Seizure. 2011; 20(10): 779-783, doi: 10.1016/j.seizure.2011.07.010, indexed in Pubmed: 21821437.

13. Saygi S, Erol i, Alehan F. Early clinical predictors of intractable epilepsy in childhood. Turk J Med Sci. 2014; 44(3): 490-495, doi: 10.3906/sag1302-4, indexed in Pubmed: 25558654.

14. Smith D, Defalla BA, Chadwick DW. The misdiagnosis of epilepsy and the management of refractory epilepsy in a specialist clinic. QJM. 1999; 92(1): 15-23, doi: 10.1093/qjmed/92.1.15, indexed in Pubmed: 10209668

15. Patil M, Malik S. JoshiM, Gajre M.Early Predictors of Intractable Childhood Epilepsy. Bombay Hospital Journal. 2009; 51(1): 36-43.

16. Kwan P, Brodie MJ. Clinical trials of antiepileptic medications in newly diagnosed patients with epilepsy. Neurology. 2003; 60(11 Suppl 4): S212, doi: 10.1212/wnl.60.11_suppl_4.s2, indexed in Pubmed: 12796516.

17. Berg AT, Scheffer IE. New concepts in classification of the epilepsies: entering the 21st century. Epilepsia. 2011; 52(6): 1058-1062, doi: 10.1111/j.1528-1167.2011.03101.x, indexed in Pubmed: 21635233.

18. Ohtsuka $Y$, Yoshinaga $H$, Kobayashi $K$, et al. Predictors and underlying causes of medically intractable localization-related epilepsy in childhood. Pediatr Neurol. 2001; 24(3): 209-213, doi: 10.1016/s08878994(00)00269-1, indexed in Pubmed: 11301222
19. Manoj G, Sushma M, Surekha J, et al. Early predictors of intractable childhood epilepsy. Bombay Hospital Journal. 2009; 51(1): 36-43.

20. Moinuddin A, Rahman MM, Akhter S, et al. Predictors of Childhood Intractable Epilepsy- A Retrospective Study in A Tertiary Care Hospital. Bangladesh Journal of Child Health. 1970; 33(1): 6-15, doi: 10.3329/bjch.v33i1.5669

21. Joseph I, Timothy A, Janet L. Evaluation and management of drug - resistant epilepsy. Wolsters Kluwer Health. http://www.uptodate. com (2012).

22. Eriksson KJ, Koivikko MJ. Prevalence, classification, and severity of epilepsy and epileptic syndromes in children. Epilepsia. 1997; 38(12): 1275-1282, doi: 10.1111/j.1528-1157.1997.tb00064.x, indexed in Pubmed: 9578522.

23. Chawla S, Aneja S, Kashyap R, et al. Etiology and clinical predictors of intractable epilepsy. Pediatr Neurol. 2002; 27(3): 186-191, doi: 10.1016/s0887-8994(02)00416-2, indexed in Pubmed: 12393128.

24. Camfield P, Camfield C. Epileptic syndromes in childhood: clinical features, outcomes, and treatment. Epilepsia. 2002; 43 Suppl 3 : 27-32, doi: 10.1046/j.1528-1157.43.s.3.3.x, indexed in Pubmed: 12060004.

25. Berg AT, Berkovic SF, Brodie MJ, et al. Revised terminology and concepts for organization of seizures and epilepsies: report of the ILAE Commission on Classification and Terminology, 2005-2009. Epilepsia 2010; 51(4): 676-685, doi: 10.1111/j.1528-1167.2010.02522.x, indexed in Pubmed: 20196795.

26. Shinnar S, Berg A, O'Dell C, et al. Predictors of multiple seizures in a cohort of children prospectively followed from the time of their first unprovoked seizure. Annals of Neurology. 2001; 48(2): 140-147, doi: 10.1002/1531-8249(200008)48:2<140::aid-ana2>3.0.co;2-y. 